\title{
Between Cause and Cure. The Mining Industry and HIV/AIDS Governance in South Africa
}

\author{
Jana Hönke
}

\section{Introduction}

The story of HIV/AIDS and the mining industry in South Africa is complex. It is also more controversial than that of other sectors discussed in this volume. Two interrelated factors account for the particularity of the case. Firstly, mining companies have contributed significantly to the spread of HIV/AIDS through the use of their 120 year-old migrant labor model. At the 2010 HIV/AIDS conference in Durban, the South African gold mining sector came under heavy criticism from medical practitioners, ex-miners, advocacy groups and the South African Minister of Health for its part in the tuberculosis crisis that affects the industry and its workforce. An activist with the Aids and Rights Alliance for Southern Africa referred to the industry as "TB factory”" The health minister, Mr. Motsoaledi, stated that "[if] TB/HIV is a snake in Southern Africa, we know that its head is in South Africa in the mines. We are exporting TB and HIV throughout the region”. ${ }^{2}$ Secondly, the mining industry was early in identifying HIV/AIDS as a key risk to its operations. Already in the 
mid-1980's initial responses were developed. However, the overall exclusionary nature of these first approaches laid the ground for some of the difficulties in the implementation of comprehensive prevention and treatment policies later on. The analysis of the mining sector provides important insights into the specific political and normative conditions under which companies have historically addressed a problem such as HIV/AIDS in a way that contributes to improved collective goods provision.

Apart from the transport sector (30 per cent), the mining industry has the highest prevalence rate of HIV/AIDS among its workforce (23-28 per cent) (Vass 2003, automotive only 4-9 per cent). In addition, the mining industry has seen a rise of opportunistic diseases such as TB and malaria. This high prevalence rate can be attributed to the labor-intensive model of mining in South Africa based on cheap, unskilled migrant labor. Moreover, the mining industry was a central actor in the process of institutionalizing racist segregation in South Africa. Since the opening of the first mines in 1886 the industry was based on a racial model of migrant labor (Murray 1982, Lipton 1985). Africans from all over Southern Africa were brought to the mines and housed in single-sex hostels while their families had to stay in their home regions. The Chamber of Mines (CoM) played a key role in introducing and maintaining the migrant and compound system. It benefited from governments that backed racial segregation in society and facilitated recruitment of labor from neighboring countries at extremely low costs (Terreblanche 2003: 65-78). This system became an important facilitator 
for the spread of HIV/AIDS among mine workers. Thus, contrary to other sectors discussed in this volume, HIV/AIDS is not only a context factor South African mining companies, due to their labor intensive business model that heavily depends on migrant labor, have to deal with. The exceptionally high prevalence rate of HIV/AIDS among mine workers is a negative externality of the South African mining industry.

The mining industry in South Africa was the first to become aware of and act upon the risk of HIV/AIDS perceiving it as a threat to productivity and profitability as early as the mid-1980s. In 1986-7, the Chamber of Mines conducted a survey among 60000 mine workers. The survey revealed that 0.3 to 4 per cent of mine workers had contracted HIV/AIDS, with the highest rate among Malawian migrant workers (Rajak 2010: 554, Dickinson 2004). The response taken by companies was, however, very restrictive. Constructing HIV/AIDS as an external and extraneous problem, companies sought to insulate themselves from the threat. For this purpose, the firms introduced pre-employment testing despite harsh critique from the unions (Crew 1992, Dickinson 2004). The Chamber of Mines stated that "[N]o known carriers will be engaged [and] and all recruits from high-risk areas will be tested at source” (Brink and Clausen 1987: 15). A medical practitioner working with Anglo American explains that: "[b]efore the advent of the ART roll-out ... they [the companies] were only interested in the negative ones and how to keep them negative, and if you were positive you were stuffed”. ${ }^{3}$

This position changed, however. The National Union of Mine Workers (NUM) continued to harshly criticize and fight against the companies' 
policy to send HIV-positive workers home. While mining companies had initially supported the insulation and repatriation approach of the National Party government, ${ }^{4}$ the changed political climate after 1989 and the new value given to human rights seemed to change the industry's stance towards the pandemic. It recognized that the spread of the disease was caused by social and economic factors for which the mining industry bore responsibility (Fourie 2006: 81-84). ${ }^{5}$ Consequently, NUM and the Chamber of Mines negotiated comprehensive workplace HIV/AIDS policies (Hermanus 1993).

Although the stage was set for a radical policy shift towards a groundbreaking and comprehensive strategy against the pandemic, the initial response to HIV/AIDS developed very slowly both within government and in much of the private sector (Nattrass 2007: 39, Ellis and Terwin 2004, and chapter $x$ in this book). This changed in 2002. During the 1990s the number and impact of HIV/AIDS infections rose dramatically. The mining industry increasingly felt the impact of the pandemic. Prevalence rates in the mining sector currently range from 16,5 per cent up to 30 per cent. ${ }^{6}$ At the same time, the implementation of the government's HIV/AIDS policy was slow and ineffective. The government under Thabo Mbeki, who took office in 1999, lacked the willingness to engage in a comprehensive HIV/AIDS policy including ART treatment. Since 1995 (Labour Relations Act) and 1998 (Employment Equity Act and Medical Schemes Act) respectively, labor regulation in the new South Africa prohibits firms to dismiss HIV/AIDS positive workers or to reduce benefits for infected workers after early retirement. These regulations 
caused a sharp rise in the companies' HIV related expenditures. Thus, in 2002, the largest private sector employer in South Africa, Anglo American, decided to take action and extended its HIV/AIDS program to include treatment as well. Other large mining firms, such as De Beers, Anglogold Ashanti or BHP, followed suit.

In the following, I analyze the activities of mining companies in South Africa to combat HIV/AIDS post-2003 and will discuss the quality and inclusiveness of corporate governance contributions in this field. This is followed by a discussion of the factors behind mining companies' more or less inclusive contributions to the collective governance of HIV/AIDS.

\section{From Exclusion to Treatment. Mining Companies` Responses to HIV/AIDS (2003-Today)}

Mining companies in South Africa were not only the first business actors to become aware of HIV/AIDS and act upon it. The scope of their engagement has also been unmatched. With the exception of the automotive industry, companies in other business sectors tend to focus less on the development of HIV/AIDS policies and their overall performance in the fight against the disease is comparatively weak (for the textile and food and beverage industries see Müller-Debus and Kranz in this volume). Medical practitioners and health personnel employed in the mining sector have also been far ahead of the government in devising and implementing appropriate policies to tackle HIV/AIDS. ${ }^{7}$ However, the reach of such private treatment programs is contested. Two aspects are important with respect to this debate. The first one concerns coverage: 
Are the HIV/AIDS workplace programs of mining firms restricted to regular employees or do they also include contract workers, partners, extended families and community members in the labor sending areas? The second concern is the variation in the engagement of small versus large firms. It was mostly large scale and medium-sized companies that had developed HIV/AIDS policies in 2003 (Ellis and Terwin 2004).

Larger mining companies have engaged at various levels and with various actors in combating HIV/AIDS. Firstly, most of these activities are situated at the workplace and reach beyond the workforce only to a limited degree. The important role of the trade union NUM is remarkable as is the degree to which the workplace programs within the sector are coordinated through the Chamber of Mines. With the evolution of corporate HIV/AIDS policies, mining companies have increasingly contracted and partnered with (I)NGOs in order to implement newly developed policies at the local level. Furthermore, mining companies have linked up with IOs, INGOs, global business associations and initiatives, as well as research institutions to develop policies and implement projects. Relations with the Mbeki government have been difficult, however. Therefore, secondly, not much exchange, capacity-building or partnerships had been taking place between companies and government at the national level until 2006/7, despite the lack of health service provision in the affected areas. In the platinum mining area of Rustenburg, in which HIV prevalence rates among mine workers are among the highest in the country (28 per cent), it was not until the end of 2005 that each district had its own hospital (Thornton 2008: 186). Although they refrained from 
cooperating with national government, companies informally engaged with local governments. This changed, however, in 2006 when AIDS denialism within national government had become less acceptable and leadership changed in the ministry of health. National government started to call upon mining companies to help with their expertise and capacities in the fight against HIV/AIDS. Firms have also entered into more and more formal partnerships with governments from the municipal to the provincial level in order to coordinate public and private HIV/AIDS programs and to extend coverage. Thirdly, mining companies have not been very active - at least not explicitly - in influencing the government's policy agenda or capacity building to improve the implementation of state programs.

\section{Companies’' In-House Policies}

As outlined above, the workforce in the mining industry is by far the most heavily affected from the HIV/AIDS pandemic compared to other industry sectors discussed in this volume. The widespread HIV/AIDS prevalence among mine workers is historically rooted in the mode of labor recruitment and in the industry's labor relations more generally. Mining companies in South Africa address HIV/AIDS mostly at the local level of the workplace and in the areas from which they source their workforce. ${ }^{8}$ Agreements between organized mine labor, most importantly between the largest South African trade union, the National Union of Mine Workers, and the Chamber of Mines, helped to facilitate the formulation and implementation of such policies. A first agreement between the Chamber 
and NUM was reached in 1991 when the fundamental principles of HIV/AIDS workplace programs in the new South Africa were defined. These principles prohibited mandatory testing, prescribed confidentiality of testing results, and committed companies to train staff for peer education and to provide benefits for sick employees. A united effort against HIV/AIDS was called for. ${ }^{9}$

As Brian Brink, chief medical officer at Anglo American, recounts, by the year 2000 investors started to see the mining industry in South Africa as 'a business that's not going to survive' and asked '[s]hould we be looking elsewhere? ${ }^{10}$ Therefore, mining companies launched an offensive and turned to a more holistic approach - as long demanded by the trade unions. While education and awareness programs had been introduced as early as 1988/9, ART treatment for workers was only rolled out by large-scale companies from 2002 onwards. Individual companies signed agreements over comprehensive HIV/AIDS workplace policies (prevention and treatment) between 2002 and 2003 which since then have provided for internal HIV/AIDS policies and have been repeatedly updated and renegotiated. ${ }^{11}$ By 2003, 77 per cent of the mines had an HIV/AIDS policy in place (as opposed to only 50 per cent of the manufacturers). However, only 21 per cent contained ART treatment (Ellis and Terwin 2004: 22-24). In 2005, Anglo American was described as the 'largest single business customer for AIDS drugs in the world' (Knight 2005: 22). Today it has about 11000 HIV-positive employees enrolled on its HIV disease-management program in South Africa. ${ }^{12}$ 
Workplace programs target workers and their families to various extents. Some of these programs reach beyond the workplace to surrounding and sourcing communities. Workplace programs include information and education, counseling and voluntary testing, and intend a general improvement of health care provisions. Since the 2000s, treatment has been increasingly included in workplace schemes, though to various degrees. Finally, company-provided home-based care services for sick or retired workers have progressively begun to engage with the consequences of HIV/AIDS. Workplace programs are run by the companies themselves or in cooperation with contractors, such as for profit service providers and NGOs. Anglo Platinum, for instance, works with the NGO Vision of the Nation and Tshupe Hospice which run homebased care centers in local communities next to the firm's mining operations. ${ }^{13}$ The independent disease management company Lifeworks trains peer educators for BHP. Peer educators are supposed to encourage workers to receive counseling and go for testing (BHP Billiton 2010, Knight 2005: 30). Home-based care programs in the communities from which employees originate are mostly run by the traditional, industryowned service provider TEBA. Founded in 1902, TEBA is the labor recruitment and management agency of the South African mining industry. Between 2001 and 2002, members of the CoM signed agreements with TEBA to provide home-based care to mine workers who have returned sick to the rural areas within South Africa. ${ }^{14}$

There is variation in the inclusiveness and scope of these programs with regard to different time periods and different companies. In most cases 
only full employees were initially covered by workplace programs. Over time, more and more companies developed broader health care facilities for families and communities from which they source labor as well as for contract labor. Part of this engagement is required by the Mining Charter (2002) and is fixed in a 2003 agreement between the Chamber and NUM on health care arrangements for dependents. ${ }^{15}$ However, when it comes to discussing the scope and inclusiveness of private health governance in the field of HIV, the most critical issue is access to treatment. Whereas most companies pursue a more exclusive approach, diamond mining company De Beers started the first treatment program that reached beyond the workplace in 2002. It covers workers and their families and is quite unique in terms of its inclusiveness as compared to other companies in the sector (Rispel et al. 2010: 394, Peterson and Shaw 2006). By contrast, BHP Billiton's workplace program is focused on the prevention of HIV among its workforce only, but does not provide ART treatment. The company supports workers to get access to private medical schemes that include HIV/AIDS treatment (Knight 2005, BHP Billiton 2008: 60). However, as opposed to gold mining companies, BHP changed its recruitment practices from migrant labor to sourcing labor from local communities in order to address one of the root causes of the spread of HIV/AIDS. ${ }^{16}$ In 2002, Goldfields provided treatment to employees only in exceptional cases such as for rape victims and to prevent mother-to-child transmission. ${ }^{17}$ One of the big debates in the mining sector in recent years has been about the issue that the mining companies and the trade unions 
do not address the needs of extended family members and the broader communities that depend on mining. ${ }^{18}$

Companies rarely extend their contributions to combating HIV/AIDS to the district or provincial level. Where this is the case it is a fairly recent phenomenon, partly triggered by a change in the government position allowing for more public-private cooperation and therewith the extension of business efforts beyond a narrow focus on the workplace to the ‘community belt' (Hönke 2012a) and beyond. De Beers was the first company to extend HIV/AIDS services to host communities. ${ }^{19}$ Others, such as Anglo American, followed suit. ${ }^{20}$ Another problem mining companies hesitate to deal with is to address the root causes of widespread HIV/AIDS prevalence in mining areas, the migrant labor system. Only BHP changed recruitment practices by privileging local over migrant labor. While all mining companies are required by the MPRDA and the Mining Charta to phase out single sex hostels and transform them into family units, BHP has been especially responsive and relocated mine hospitals to the neighboring communities (Knight 2005: 30-31).

At the global level, the South African Chamber of Mines and its prime stakeholders - large multinational companies including Anglo American, BHP, Anglogold Ashanti, Goldfields and De Beers - exchange best practices and develop voluntary best practice standards. Furthermore, they engage in corporate social investments in HIV/AIDS projects. Regarding the former, companies have supported the development of a Best Practice AIDS Standard through membership in the Global Coalition on HIV/AIDS. Concerning corporate philanthropy, companies contribute 
financially to various health care, VCT and treatment projects of the Global Coalition on HIV/AIDS. In addition, the mining industry has a sector-specific business association that is specialized in corporate social responsibility (CSR) and sustainability issues and operates at the global level. Through the International Chamber of Mines and Metals (ICMM), companies support trials for a new therapeutic vaccine for HIV/AIDS. ${ }^{21}$

Precarious Cooperation: Collective Goods Provision with Government Cooperation between public authorities and companies in addressing HIV/AIDS has been scarce and limited to prevention and to implementation issues at the local level. Mining companies send medical practitioners to serve in public hospitals on an occasional basis, or the general public is allowed to access mining hospitals at times. Some hospitals are run as public-private partnership, increasingly so since 2006. As long as the government opposed ART, companies with ART programs had to act very carefully. While the government was careful not to officially endorse such programs, it allowed companies to pursue private ART initiatives. Before 2006, only some companies engaged in partnerships with local governments in order to prevent HIV/AIDS or provide related health services in selected localities. As long as president Mbeki and his health minister Tshabalala-Msimang opposed ART treatment, cooperation in this area was difficult, risky and thus unlikely. Instead, companies contributed to awareness-raising campaigns, as for instance Harmony Gold in the Morobe district (Harmony Gold 2006: 46). Anglo Platinum initiated a comprehensive community care program with 
the title Circle of Hope in 2002. Circle of Hope seeks to minimize the impact of HIV/AIDS in Anglo Platinum's neighboring communities. Since the start of the program, the company has emphasized their aim to collaborate with local and district government, NGOs, health practitioners and traditional healers (Anglo American 2005: 89). While the program's initial focus was on care and peer education in a $50 \mathrm{~km}$ circle around its operations in the Rustenburg area, it was soon extended to provide homebased care for returned workers in the labor sending areas of the Eastern Cape (ibid).

With changing power relations in 2006 and a subsequent shift in government towards a pro-ART treatment stance, increased cooperation has become possible. Usually, cooperation still takes place at the level of the municipality or district. As a company manager explains '...there is much more like meeting sessions and all that with the government than action. [...] we rather target local government, you know. Because things tend to move faster in terms of action and implementation [...] Anyways, the national government will at the end of the day do whatever they want to do'. ${ }^{22}$ It was only in 2010 that Anglo extended its HIV policies beyond employees and dependents in a more comprehensive manner. Working with the Eastern Cape Department of Health, it supports the provincial administration to improve health service provision in four selected districts (Anglo American 2010: 21; see also the section on public private cooperation below).

Mining companies have increased their engagement for education and overall health care services (prevention/care) in neighboring communities 
and labor sending areas. However, the limited inclusiveness of the mining sector's contributions to local HIV/AIDS governance is particularly evident with regard to the companies' stance on informal settlements that are characteristic for the mining regions, such as the booming platinum mines in North-Western Province and Limpopo. Although many mine workers live in these settlements, the mines continue to refuse responsibility and ask local government to provide for services (Hamann 2008).

At the global level, the Chamber has participated in tripartite negotiation between labor and labor organizations, the labor ministries of governments and other employer organizations to develop the ILO Code of Practice on HIV/AIDS. ${ }^{23}$

\section{Impact on State Policies and Implementation}

Confronted with excessive rates of infection among its workforce and a particularly strong trade union movement, the large mining companies have long exceeded government in terms of know-how, strategies and the provision of resources for the prevention and, in particular, the treatment of HIV/AIDS. Due to negative experiences with the national government, however, they have rarely approached the government to foster public policies. The mining industry claims to have been involved in the formulation of the first South African HIV/AIDS policy under the Mandela government in 1994 as well as in the development of a comprehensive national HIV/AIDS policy in $2003 .{ }^{24} \mathrm{~A}$ tripartite forum on HIV/AIDS was established at NEDLAC in 2002/03, and together with 
government and labor, an HIV and AIDS Summit was held in 2003 at which the three parties signed a declaration. However, both strategies were slow and not successful in their implementation. Despite such formal interaction and involvement, it seems that HIV/AIDS was such an excessively politicized issue that national government opted for the delay or blockage of action. Relations between those companies that began contemplating treatment and the Mbeki government, which was against such treatment, were strained in what regards HIV/AIDS policies. As a consequence, the HIV Council was blocked for several years. When asked about their interactions with government on HIV/AIDS issues, interviewees stated that if anybody was interested in their expertise, they would not be opposed to sharing their knowledge. However, these representatives of mining firms are skeptical about working with the national government in general. ${ }^{25}$ While companies frequently exchange expertise and strategies on their HIV/AIDS policies in the context of the Chamber of Mines, these private sector efforts to approach the problem at the workplace have rarely been communicated and coordinated with public policies. Instead of involving the state, a parallel system of providing health services at the company level, including the pooling of resources with others, has developed.

There are two main reasons for why the high degree of self-regulation within the industry did not translate into an active engagement with public HIV/AIDS policies until recently: First, a lack of political will within government prevented firms from collaborating with government in efforts against the pandemic. Slow and limited policy implementation in 
the 1990s and Mbeki's denial of AIDS during his presidency led to very limited government activity to address the problem of HIV/AIDS appropriately. It was (only!) in 2003 that the ANC government decided in favor of a national HIV/AIDS treatment strategy (see chapter by MüllerDebus and Thauer in this volume). At the same time, President Mbeki and Health Minister Tshabalala-Msimang warned against the 'poisonous' effects of ART and actively obstructed delivery of treatment - even after the launching of a public ART policy. Government reactions to Anglo American's new treatment program, launched in 2002, prove insightful. Rajak reports how Anglo American managers never got tired of describing the company's heroic 'coming out' with an HIV program against the health minister, describing how 'she was really pissed-off' and felt that the company was 'squeezing' her (Rajak 2010: 557, Von Soest and Weinel 2006, Müller-Debus 2006: 18). Anglo, at the same time, presented its action as a moral mission. However, there is little doubt that the new program was also a reaction to increased labor and health costs caused by the HIV pandemic (ibid.). While Anglo took action early on, other companies refrained from publicly opposing the President's position. Formerly employed at the department of health, the health manager who developed BHP's HIV/AIDS policy in 2002/3 put strong emphasis on VCT, yet did not include ART treatment in the company program. $^{26}$

Second, the ANC government meets the mining industry with suspicion and mistrust. Since the mining industry is responsible for the high HIV/AIDS prevalence among its workforce, it is expected to address the 
problem. The change in government policy has come about without significant business involvement. One may argue that the decision by Anglo American to engage in treatment in 2002 had significant political ramifications. However, informants disagree on the extent to which Anglo's decision directly catalyzed the national roll-out of ART to which the South African government committed in 2003. What can be said with certainty is that Anglo Americans unilateral decision was not well received by the minister of health and triggered serious tensions between government and the company, according to the accounts of several AngloAmerican executives (see above).

Two developments may result in changing patterns of HIV/AIDS policies leading to increased cooperation between public and private actors. First, the ANC government adopted a new position and came up with a strategic plan to combat HIV/AIDS 2007-2011. As part of a change in leadership within the health ministry in 2006, the responsibility for HIV/AIDS policy was transferred from the health minister to the deputy president and the deputy health minister. The South African National Aids Council (SANAC) was restructured and conducted consultations between government, civil society and business about the new National HIV/AIDS policy. The mining industry became part of it in 2007 and CoM was involved in formulating the new National Strategic Plan on HIV and STIs 2007-11. ${ }^{27}$ Moreover, president Zuma appointed Mr. Motsoaledi as the new health minister in 2009. Described as a respected medical practitioner and former provincial minister, he has fostered ties with leading HIV/AIDS activists and NGOs in order to change the way HIV/AIDS is 
treated by the government in South Africa. ${ }^{28}$ Thanks to these developments, mining companies, local governments and public health practitioners increasingly partner in running hospitals and combining company-internal ART programs that include easier access to the public roll-out of treatment through medical aid schemes. ${ }^{29}$

Second, the scope of the initial workplace-approach of many companies has proven too limited to effectively tackle a task as complex as the HIV/AIDS pandemic. It has become evident that effective treatment will only be achieved if the extended family of mine workers is involved in anti-retroviral therapies. The elimination of important veto players within government and, at the same time, the need for more broad-based and complex strategies to combat HIV/AIDS might lead to more pro-active co-operation between private and public actors. Mining companies have focused on providing a comprehensive HIV/AIDS policy as a club good that is to workers, to dependents (to some degree), and in some cases also to neighboring and sending communities. Regarding the latter, however, services are limited to education and prevention as well as support for improved general health services; but these services do not offer HIV/AIDS testing and treatment. Public contributions to combating HIV/AIDS have improved a lot but are still limited by a lack of resources and other capacities. ${ }^{30}$

\section{Mining Companies Against HIV/AIDS - When and How Inclusive}

Assessments of the role of mining companies in combating HIV/AIDS in South Africa are split into two camps: those who highlight the 
achievements of private efforts against the pandemic and see the companies' engagement as a reflection of their ethical stance; and those who criticize these efforts as insufficient and as a mere publicity tool as they point to the legacy and responsibility of the industry for the pandemic (Rajak 2010). Speaking to companies and reading their individual or business association reports, we are presented with the first narrative, which highlights the business case for HIV/AIDS. In difference to the automotive industry, however, the business case in the mining industry is not attributable to asset specificity - high investments in rare skills of employees (Thauer 2012). Compared to the automotive sector, the mining industry does not qualify as a high-skills industry. Instead, HIV bears heavily on the productivity and costs of mining operations on account of the sheer size of the problems caused by the disease. We must remember that the prevalence rates in this industry are much higher than in any of the other industry sectors analyzed in this volume. At the same time, the public sector is unwilling or unable to combat the disease. The government's inactivity to render health services can be interpreted as a shadow of anarchy under which mining companies decided to address HIV/AIDS with their own means.

The companies' decision for this was also based on the calculation of the cost incurred by HIV/AIDS without a workplace policy: BHP estimates that for every dollar invested in training, education and medical programs, the return was fourfold in terms of benefits like retraining, absenteeism and productivity. ${ }^{31}$ Goldfield claims it lost about $5 \$$ per ounce of gold produced in South Africa as a result of HIV. The medical consultant with 
Anglo, Brian Brink, and Anglo’s current chief medical officer, Jan Pienaar, report that without a treatment program HIV/AIDS would cost the company 5 per cent of its payroll (Brink and Pienaar 2007: 79). In the later stages of the infection, workers lose up to 15 workdays a month. When they leave work or die in the mines, companies have to pay sickness benefits or pensions to their families, as Brian Brink of Anglo explains. ${ }^{32}$ Preventive HIV/AIDS policies and treatment are also financed by companies because this promises to be more cost-effective compared to the overall costs non-action would cause (see for instance Rosen et al. 2003).

Another aspect of the first, positive, narrative is that this business case for HIV/AIDS is presented as a moral mission of companies who would fight the pandemic against all odds, such as irresponsible or weak government. It serves to increase the companies' reputation and improve their public image (see Rajak 2010: 552-3). Critical voices emphasize instead the exploitative practices of the industry, which are related to the labor recruitment model and a root cause of the exceptionally high HIV prevalence rates in the mining areas and in labor sending communities. From the critics' point of view, companies engage in corporate social spending more generally and specifically in HIV/AIDS policies out of reputational concerns. CSR activities, it is argued, are deployed to disguise structural inequalities as well as current and past exploitation and public bads caused by the very same industry (see Marks 2006, Fig 2005). Either way, reputational concerns and public pressure provide also incentives for mining companies to engage in HIV/AIDS governance. 
It has so far been argued that mining companies' activities in the field of HIV/AIDS can be attributed to two factors. First, an appropriate state response to HIV/AIDS is lacking. This imposes considerable costs on mining companies which are faced with extremely high prevalence rates (shadow of anarchy). Second, mining companies engage in the struggle against HIV/AIDS out of reputational concerns. However, these two factors cannot account for the variance of responses of mining companies in South Africa to the HIV/AIDS pandemic at different points in time. The degree of inclusiveness and exclusiveness of the companies' programs differs widely over time. In the following, I will argue that a shadow of hierarchy cast by the post-apartheid South African state and the post-apartheid normative context played important roles in turning the companies' response to HIV/AIDS from an exclusionary to a more inclusive approach.

The post-apartheid ANC responded slowly to the pandemic and subsequently opposed ART treatment (see Nattrass 2007). In a meeting with the Mines Safety and Health section in the Department of Minerals and Energy in 2007, government representatives explained that they only started looking into the issue of HIV in 2006 and emphasized repeatedly that they were only starting to get active now, still figuring out the relationship between occupational health and HIV/AIDS. ${ }^{33}$

However, the shadow of anarchy did not only result from a lack of state capacity, but also from a lack of willingness. More importantly, the mining companies' contributions to the governance of HIV/AIDS only started in the late 1990s, even though they had felt the impact of the 
pandemic much earlier and the government had not effectively addressed the issue throughout the 1980s and early 1990s. Finally, companies developed different responses at different moments in time to address the challenge of HIV/AIDS under conditions of limited statehood in South Africa. We observe strategies of exclusion and insulation as well as the provision of HIV/AIDS health services. As far as the latter is concerned, the degree of inclusiveness can range from narrow club good to contributions to health as public good. In the 1980s, companies opted for an exclusionary approach, trying to insulate themselves from the pandemic instead of providing treatment. Through the use of preemployment testing, companies tried to prevent HIV-positive workers from entering the company. Employees who were unable to continue their work due to an HIV/AIDS infection were simply dismissed. This was possible because the mining industry is based on low-skilled, mass labor. It thus becomes clear that the shadow of anarchy is not an incentive to engage in inclusive governance as such; instead, cost-effective solutions can be exclusionary and private-good oriented.

However, the changing normative context after the end of apartheid rendered such an approach impossible. While the ANC government remained largely inactive in the area of HIV/AIDS, new norms became institutionalized in the South African labor regulation, effectively changing the cost calculation of firms in the field of health. Even though companies faced a lack of state action against HIV/AIDS, they did not operate under a complete shadow of regulatory anarchy in this field post1990. Newly designed labor regulations now prohibit mandatory testing 
and automatic dismissal due to an HIV infection. This regulation effectively casts a shadow of hierarchy over companies. Furthermore, companies are bound to guarantee the same pension and home-based care benefits to early retired HIV-positive workers and dependents of deceased workers as to everybody else. The Prescribed Minimum Benefit Amendment of 2005 obliges companies to include HIV testing, care and treatment in their medical aid schemes (Mahajan et al. 2007: 3). Finally, the new Mining Charta commits companies to improve the living conditions of mine workers, to develop integrated rural development plans for labor-sending areas, and to improve the standard of housing, which includes upgrading hostels into single accommodation and family units. ${ }^{34}$ All of these newly established labor regulations (shadow of hierarchy) have increased the companies' costs in relation to the HIV/AIDS pandemic considerably.

Changes in the normative context were not bound to post-apartheid South African law but extended to the international level throughout the 1990s, posing a clear threat to the reputation of mining companies. By the late 1980s and early 1990s, mining companies in South Africa understood the need to improve their negative image in order to reintegrate and prosper in a global economy and a new South Africa. Reintegrating themselves as good corporate citizens into the global economy became a new imperative and companies increasingly committed to global norms of CSR. Companies had a double incentive to do so. On the one hand, major mining companies such as the Anglo American Group and Billiton shifted their primary listings to the London stock exchange in 1999 and 1997 
respectively, subjecting themselves to new standards (Chabane et al. 2006: 559). On the other hand, the political position of mining companies in South Africa was vulnerable throughout the 1990s. Several companies were seen as having directly or indirectly supported the apartheid regime, a charge confirmed by the Truth and Reconciliation Commission (Nattrass 1999). In order to comply with the demands of shareholder capitalism and to gain legitimacy in the eyes of foreign shareholders, the South African government and society at large, major companies embraced the agenda of corporate citizenship and CSR (Hönke et al. 2008). They sought to change their image from collaborators and profiteers of racial segregation and oppression to the economic backbone of the developmental aspirations of the new South Africa and as socially responsible (Fig 2007, Hamann 2004).

Despite the importance of reputational concerns, pressure exerted by NGOs seems to have played only a minor role in motivating companies to take action against HIV/AIDS. NGOs such as the Treatment Action Campaign were among the most important actors to push the South African government as well as pharmaceutical companies to provide for comprehensive and affordable HIV/AIDS treatment. They were, however, less relevant for pushing mining companies into action. Nevertheless, the National Union of Mineworkers was instrumental in shaping how mining companies reacted to HIV/AIDS. NUM campaigned for nondiscrimination at the workplace and convinced companies to drop exclusionary policies in exchange for a rights-based and inclusive HIV/AIDS-workplace policy. Tracy Peterson, who developed the first 
comprehensive HIV/AIDS policy for De Beers, recounts how the draft of the policy was blocked by NUM until De Beers, after rounds of negotiations, finally agreed to include treatment in the program. The policy was subsequently announced in $2002 .{ }^{35}$ However, NUM's position on HIV/AIDS, largely shaped by the experience of workers who lost their jobs or were expelled from the country, has sometimes become an obstacle to combating HIV/AIDS comprehensively. Protecting workers from having to expose their status (abolishment of mandatory testing) is commendable, but it becomes problematic when it helps to keep an aura of confidentiality and stigma around HIV (Dickinson 2009). ${ }^{36}$

What are the other factors that explain the different degrees of inclusiveness and effectiveness of mining companies' contributions to combating HIV/AIDS? The size and capacity of a company plays a major role. ${ }^{37}$ HIV/AIDS policies are expensive, in particular when it comes to treatment. Medium-sized South African gold miner Harmony Gold, for instance, only provides ART to employees and, in contrast to mining giants such as Anglo American or De Beers, is less engaged in mining communities.

The evidence from the mining sector suggests that the willingness and capacity of the state may not be a precondition for companies to address HIV/AIDS. However, political leadership and resources effectively influence how inclusive and effective companies’ HIV/AIDS policies turn out to be. Private HIV/AIDS governance contributions are more inclusive if companies cooperate with local governments, as envisaged in partnering programs with local governments since 2007. At the same 
time, however, state actors may also prevent private governance contributions. The anti-ART position of the Mbeki-government has clearly delayed, if not obstructed an earlier engagement of companies regarding treatment. This is reflected in the above mentioned negative reaction of the South African health minister to Anglo American's initiative to provide treatment. Furthermore, De Beers reported how its policy got delayed by the government while other companies refrained from certain policies entirely in order to avoid trouble with the government. Relations between the government and mining companies on the issue of HIV/AIDS have been strained. Not only did the government refrain from taking national leadership for a comprehensive HIV/AIDS policy for so long; it was in fact a stumbling block: officials interfered with and delayed private treatment initiatives. ${ }^{38}$

Finally, the effectiveness of the companies' governance contributions is limited by stigma. To talk about sex openly is still a problem in South Africa and prevents people from testing but also from seeking treatment at an early stage (Dickinson 2009). Company-run programs are particularly hampered by a lack of confidentiality and the fear of losing the job; this, in consequence, results in low rates of VCT or treatment uptake (see for instance Bhagwanjeel et al. 2008). In addition, public statements by leading politicians, not only by Mbeki and Tshabalala-Msimang, but also by the current president Jacob Zuma, have contributed to a persistent denial of HIV and an acknowledgement of the causal nexus between certain sexual practices and the disease. 


\section{Conclusion}

The mining industry contributes considerably more to the governance of HIV/AIDS compared to the other industry sectors analyzed in this volume. Comparable commitment can only be found in the automotive sector. It is on a much higher level than in the textile, food and beverage industries. Medical practitioners and health managers working with some of the large mining companies in South Africa have been at the forefront of developing appropriate strategies to address the epidemic. At the same time, mining companies contribute to the high HIV/AIDS prevalence rates in an important way. Thus, compared to other industry sectors, the normative or moral pressure on mining companies is higher since these companies are not only part of the cure but also part of the problem, namely the rapid spread of the pandemic in Southern Africa. Reduced profitability due to the costs caused by HIV/AIDS, and reputational costs on account of the companies' responsibility for the spread of the pandemic are two drivers of the strong engagement of mining companies against HIV/AIDS. Finally, the shift in the mining companies' response to HIV/AIDS - from an extremely exclusionary, insulating strategy in the 1980s to a treatment strategy after 2002 - highlights the role of norms and institutions in forming the decision-making of companies as to how inclusive or exclusive they will react to the shadow of anarchy.

I conclude this chapter by outlining three problems concerning mining companies' contributions to the governance of HIV/AIDS and what they teach us about the privatization of governance more generally. Firstly, Rajak has recently argued that - quite opposite to the late 1980s - 
company managers she interviewed presented the business case for HIV/AIDS as a moral mission and stressed that it was the responsibility of the companies to do something to improve the lives of all. Yet, these same managers externalized HIV as a social risk that comes from outside and threatens productivity and profit. As one of the managers Rajak spoke to put it there were "things in the country happening [...] such as [...] HIV [...] things which are not caused by the company [...] but we are getting zapped by it” (cited from Rajak 2010: 557). This shows that there is still a tension between corporate social responsibility and externalization, between presenting the firm as providing a solution for a certain problem without acknowledging the fact that they are also a cause of it.

Secondly, despite increased public engagement and inclusiveness of programs, the problem of exclusiveness remains. Companies contribute to the improvement of services that aim at the prevention and treatment of HIV/AIDS. However, due to the strong focus on workplace programs, inequalities in terms of access to care and treatment are deepened. Insulation and fragmentation seem to be problematic outcomes of privatized governance more generally (Hönke 2012a: 11-16). At the same time, there are ethical problems attached to promoting firms as paternalist governance providers. Companies become highly involved in regulating the workers' private lives while, at the same time, they increase the workers' dependency on them.

Thirdly, there are also broader political consequences resulting from the pluralization of governance actors. The business and governance literature, and especially that on CSR, looks mainly at what Avant et al. 
(2010: 358) refer to as 'virtuous cycles' of better collective goods provision and regulation for the public good. Others, however, have argued that 'vicious cycles' towards overlapping and competing rules and non-governance, degrading accountability, fragmentation and exclusiveness of governance will prevail empirically. Non-state actors may thus eventually reduce the provision of collective goods because of the limited scope of their mandates and activities, and because of their negative effects on governance by states. There is significant variation in what we find empirically and there is evidence supporting both tendencies. Thus, more systematic attention needs to be paid to the different degrees of inclusiveness of business governance contributions and their broader and longer-term effect on public goods provision, justice and equality (see Hönke 2012b: 19).

\section{Notes}

1. See http://www.aidsmap.com/South-African-gold-mines-a-TB-factoryactivist-claims/page/1439030/ [accessed 23 August 2011]

2. Ibid.

3. Anglo American medical practitioner, cited in Rajak (2010: 55).

4. Fourie (2006: 82f.) argues that the mining industry maintained a less radical position than the apartheid government. While the government promoted a policy of mandatory testing and the repatriation of any HIV positive 'foreigner', including those South Africans who were forced to live in semi-independent reservations, the companies allowed people to work until they were too ill to do so. They also embarked on 
comprehensive education programs about the disease already in the 1980s. Yet, although the companies partially accepted workers' rights and, in addition, appealed to the government not to deny the acuteness of the epidemic, they did not put a stop to the practice of migrant labor and hostel accommodation, nor did they engage in providing any form of treatment.

5. A report by Finance Week (6-12 April 1989, as cited in Fourie (2006: 84,fn.61) on these findings led to negotiations over HIV/AIDS workplace policies between mines and NUM.

6. 16,5 per cent is the average HIV prevalence rate for Anglo American, see AngloAmerican (2010: 18-19). 30 per cent are reached at the Vaal River sites of Anglogold Ashanti (see AngloGold Ashanti 2008: 38).

7. Fourie (2006), Interview with Director of the Centre for Sustainability in Mining and Industry, 16 March 2007, Johannesburg, South Africa; interview with DME health and safety department, 27 March 2007, Pretoria; interview with CSR specialist with De Beers, 19 March 2007, Johannesburg.

8. While recruitment from the local communities in which the mines are located has increased recently, traditionally most of the labor force migrates to the mines from poor rural areas within South Africa (in particular from ex-homeland areas in Eastern Cape and North-Western Province) or from outside South Africa (Malawi, Mosambique, Lesotho). It is these rural areas which depend most on mine wages (for an overview see Malherbe 2000: 31-38).

9. See: 
http://www.bullion.org.za/Departments/Health/Downloads/HIV\%20AIDS 07.pdf, p. 2 [ accessed 23 August 2011].

10. Parker, Faranaaz (2010) 'Sex Talk a Setback for Aids', Mail and Guardian, 7 May 2010, http://mg.co.za/article/2010-05-07-sex-talk-asetback-for-aids, [accessed 22 August 2011].

11. See for instance the agreements of De Beers 2003 HIV/Aids joint Workplace Policy:

http://allafrica.com/download/resource/main/main/idatcs/00010811:96d8c de46015f75a435da884ee12a415.pdf; Anglogold Ashanti 2002 http://www.anglogold.co.za/subwebs/informationforinvestors/ReportToSo ciety03/pdf/AngloGold_NUM_agreement.pdf and Goldfields 2001 https://members.weforum.org/pdf/Initiatives/GHI_HIV_Goldfields_Appe ndixA.pdf [all accessed 13 October 2011].

12. Smallhorne, Mandi (2011) 'Developing proper policies', Mail and Guardian, 11 July 2011, http://mg.co.za/article/2011-07-08-developingproper-policies [accessed 23 August 2011].

13. Cf. Anglo Platinum (2010: 138ff); Anglo American Community Development, http://www.angloplatinum.com/safety/safety_sub/community.asp, [accessed 24 August 2011].

14. See http://www.teba.co.za/. TEBA implements development projects for the Chamber of Mines in Eastern Cape and Lesotho. It runs homebased care programs for Anglogold Ashanti, Goldfields, Lonmin, Impala, BHP; Anglo Coal and Harmony among others. See: 
http://www.teba.co.za/beta/tebadev/sponsors.asp [both accessed 23 August 2011].

15. See http://www.bullion.org.za/Departments/IRS/IR.htm [accessed 23 August 2011].

16. Ibid.; interview with Health Manager, BHP Billiton, November 2007, Johannesburg, South Africa.

17. Case Study Gold Fields, WEF Global Health Initiative, Private Sector Intervention Case example, 2002:

https://members.weforum.org/pdf/Initiatives/GHI_TB_CaseStudy_Goldfi elds.pdf [accessed 20 August 2011]; interview with Senior Manager Health Care Services, Goldfields, 2 October 2007, Johannesburg. 18. Interview with Director of the Centre for Sustainability in Mining and Industry, 16 March 2007, Johannesburg, South Africa.

19. Interview with CSR specialist with De Beers, 19 March 2007, Johannesburg; see also De Beers (2010: 61).

20. See Anglo American (2010: 21).

21. See http://www.icmm.com/page/2412/member-companies-supportleading-research-for-hiv/aids-vaccine [accessed 20 August 2011].

22. Interview with Harmony Gold representatives, 2 October 2007, Randfontain.

23. See ILO (2001) 'An ILO Code of Practice on HIV/AIDS and the World of Work', Geneva:

http://www.ilo.org/wcmsp5/groups/public/@ed_protect/@protrav/@ilo_ai $\underline{\text { ds/documents/normativeinstrument/kd00015.pdf }}$ [accessed 23 August 2011]. 
24. See:

http://www.bullion.org.za/Departments/Health/Downloads/HIV\%20AIDS 07.pdf [accessed 20 August 2011].

25. Interview with Harmony Gold representatives, 2 October 2007, Randfontain; interview with CSR specialist with De Beers, 19 March 2007, Johannesburg; interview with representative for health, Chamber of Mines, 19 March 2007, Johannesburg.

26. Interview with former health manager of BHP, October 2007, South Africa. What the company did, however, was to offer financial support to workers so that they could privately access a public medical aid scheme including ART.

27. See $\quad$ http://www.sanac.org.za/page/27/History/ and http://www.bullion.org.za/Departments/Health/Downloads/HIV\%20AIDS 07.pdf [accessed 20 August 2011].

28. See Govender (2009) 'SA won't meet ARV roll-out target, says Motsoaledi', Mail and Guardian, 15 September 2009, http://mg.co.za/article/2009-09-15-sa-wont-meet-arv-rollout-target-saysmotsoaledi [accessed 20 August 2011].

29. Interview with DME health and safety department, March 2007, Pretoria; interviews with mining companies in Johannesburg, 2007 and 2008.

30 See for instance Govender (2009) ‘SA won’t meet ARV roll-out target, says Motsoaledi’, Mail and Guardian, 15 September 2009 http://mg.co.za/article/2009-09-15-sa-wont-meet-arv-rollout-target-says-

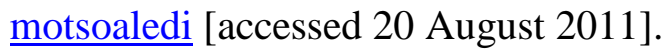


31. Stablum, Anna (2007) 'Is HIV a Time Bomb Under the Mining Industry?', Reuters , 11 July 2007

http://www.reuters.com/article/2007/07/11/us-aids-mining-

idUSL0263192420070711, [accessed 20 August 2011].

32. See http://mg.co.za/article/2010-05-07-sex-talk-a-setback-for-aids [accessed 5 February 2012].

33. Interview with DME health and safety department, 27 March 2007, Pretoria.

34. See Broad-Based Socio-Economic Empowerment Charter for the South African Mining, Industry, 2002:

http://www.cidafund.co.za/charters/miningCharter.pdf [accessed 23 August 2011]. A new charter has been launched in 2010.

35. Interview with CSR specialist with De Beers, 19 March 2007, Johannesburg.

36. Interview with Director of the Centre for Sustainability in Mining and Industry, 16 March 2007, Johannesburg, South Africa.

37. See for instance Smallhorne, Mandi (2011) 'Developing proper policies’, Mail and Guardian, 11 July 2011, http://mg.co.za/article/201107-08-developing-proper-policies [accessed 23 August 2011].

38. Interview with De Beers representative, 19 March 2007, Johannesburg; interview with Director of the Centre for Sustainability in Mining and Industry, 16 March 2007, Johannesburg, South Africa. 